\title{
Pre-Treatment and Post-Treatment Anxiety, Depression, Sleep and Sexual Function Levels in Patients with Breast Cancer
}

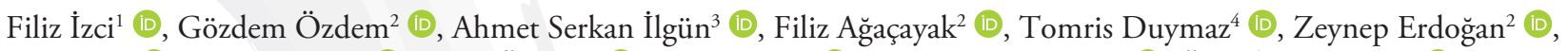

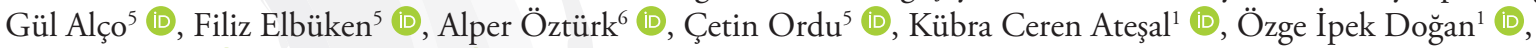
Fatma Aktepe ${ }^{5}$ (D), Vahit Özmen ${ }^{7}$ (D)

${ }^{1}$ Department of Psychiatry, İstanbul Erenköy Training and Research Hospital, İstanbul, Turkey

${ }^{2}$ İstanbul Florence Nightangale Hospital, Breast Health Center, İstanbul, Turkey

${ }^{3}$ Department of General Surgery, İstanbul Taksim Training and Research Hospital, İstanbul, Turkey

${ }^{4}$ Department of Physiotherapy and Rehabilitation, İstanbul Bilgi University Faculty of Health Sciences, İstanbul, Turkey

${ }^{5}$ Gayrettepe Florence Nightingale Hospital, Breast Health Center, İstanbul, Turkey

${ }^{6}$ Department of General Surgery, Biruni University School of Medicine, İstanbul, Turkey

${ }^{7}$ Department of General Surgery, İstanbul University İstanbul Faculty of Medicine, İstanbul, Turkey

\section{ABSTRACT}

Objective: In the phase of diagnosis and treatment of breast cancer cases, patients can usually experience sexual dysfunctions, sleep disorders and psychiatric disorders such as anxiety and depression. The main objective of our research is to study of the pre-treatment and post-treatment anxiety, depression, sleep and sexual function levels in the patients with breast cancer.

Materials and Methods: Fifty-six patients with breast cancer and 52 healthy women have participated in our study. In order to determine the anxiety, depression, sleep and sexual function levels, Sociodemographic and Clinical Data Form, Hospital Anxiety Depression Scale (HADS), Pittsburgh Sleep Quality Scale (PSQI) and Arizona Sexual Experiences Scale (ASEX) scores are utilized at pre-treatment and post-treatment phases for patients with breast cancer and our control group.

Results: According to scale scores applied to patients and control group, it has been determined that patients with breast cancer HADS sexual and sleep disorders, that their HADS and PSQI scores were higher and that ASEX scores decreased significantly ( $<0.05$ ). According to the scale scores calculated before and after treatment, there was a significant decrease in HADS and PSQI scores, whereas SEX scores have been increased significantly $(\mathrm{p}<0.05)$.

Conclusion: According to the findings of our study, anxiety, depression, sexual dysfunction and sleep disorders in patients with breast cancer are far more explicit in the pre-treatment phase than post-treatment phase. Therefore, it is crucial to psycho-socially support patients with breast cancer in the early periods before starting the treatment after diagnosis.

Keywords: Anxiety, breast cancer, depression, sexual function, sleep quality

Cite this articles as: İzci F, Özdem G, İlgün AS, Ağaçayak F, Duymaz T, Erdoğan Z, et al. Pre-Treatment and Post-Treatment Anxiety, Depression, Sleep and Sexual Function Levels in Patients with Breast Cancer. Eur J Breast Health 2020; 16(3): 219-225.

\section{Introduction}

Breast cancer is the most common cancer type in women around the world, with 1 of 8 women being diagnosed with breast cancer during their lives (1). Most of the patients who receive diagnosis of breast cancer experience psychological reactions such as denial, anger or fear against the breast cancer after the start of treatment as well as during the treatment (2). Following the diagnosis of breast cancer, most of the patients with breast cancer face fatigue, depression, anxiety, mood disorders, sleep disorders and sexual problems (3). Depression prevalence is high in the first year following the diagnosis of breast cancer, and three studies having the highest depression prevalence in a systematic compilation contain the patients who are in the first year of the diagnosis (4). Another study illustrated that depression prevalence was around $32.8 \%$ among the breast cancer cases in a large sample of breast cancer. Moreover, it has been reported that $40 \%$ of the patients who Hospital Anxiety Depression Scale (HADS) recurrence have HADS high anxiety and depression scores (5). It has been determined that $42 \%$ of the patients with advanced breast cancer HADS psychiatric disorder; and 35.7\% of them HADS depression or anxiety or both (6).

Insomnia is one of the most common cancer symptoms, which is even more common in breast cancer cases and affect $42-69 \%$ of the patients with breast cancer (7). While insomnia may increase the risk of depressive symptoms and anxiety symptoms, sometimes depressive symptoms and anxiety symptoms may contribute to the progress of insomnia (8). 
Sexual life in cancer patients may be affected by unexpected cancer diagnosis, changes in age-related sexual functions (such as menopausal changes in women), changes in body image caused by cancer treatments, infertility, fatigue, pain, and communication problems with the partner before diagnosis. Sexual dysfunction in patients with breast cancer is usually caused by many factors rather than a single factor (9). Mastectomy operation due to cancerous breast tissue presents a threat to the sexuality, motherhood, charm and body image of women, since woman breast is one of the most prominent symbols of femininity and sexuality in the female body and also it is a very important organ for the woman. It is stated that surgical, radiotherapy, chemotherapy or hormonal treatment for breast cancer affect the physical health of patients including their sexual life (10).

In our study, we aimed to examine the pre-treatment and post-treatment anxiety, depression, sleep and sexual function levels in patients with breast cancer.

\section{Materials and Methods}

After having obtained the approval from The Demiroğlu Bilim University Ethics Committee, literate patients with early breast cancer, who applied to The Breast Health Center between August 2017-Februrary 2018, aged between 18-65, who has no chronical disease and who accepted to take part in the study, were prospectively included in our study. The patients, who HADS alcohol abuse/substance use or who HADS psychiatric disorder such as schizophrenia or who HADS mental retardation, were excluded from the study. Control group consisted of volunteers who accepted to take part in our study, normalized in terms of age, were literate, were healthy in body and mind, who have not taken medicine, alcohol and psychoactive substance and who were not smokers. Written informed consent was obtained from all participants.

\section{Data collection tools}

In our study, Sociodemographic and Clinical Data Collection Form, Clinical Interview Scale - Clinical Version configured for DSM-IV Axis Diagnosis (SCID-I/CV), HADS, Pittsburgh Sleep Quality Scale (PSQI), Arizona Sexual Life Scale (ASEX) scores have been calculated for patients with breast cancer and for individuals in our control group. The evaluation based on the scores have been studied before the treatment (after establishing the diagnosis) and after the completion of the treatment.

\section{Sociodemographic and clinical information}

This form consists of questions such as age of the patient, marital status of the patient, educational background of the patient, regular partner status, sex frequency, insomnia problem and sexual problem existence which is filled out by the researcher physician.

\section{SCID-I/CV}

SCID-I is a clinical interview for DSM-IV Axis I disorders structured by First et al. (11) in 1997. Its acceptability and reliability studies for Turkey have been already done (12).

\section{Key Points}

- Sleep and sex is a necessity for patients with breast cancer.

- Mental health quality is essential for cancer treatment.

- Cancer treatment may affect sleep and sex levels.

- Cancer treatment can affect the level of anxiety and depression.

\section{ASEX}

ASEX is a scale developed by McGahuey et al. (13) in order to measure changes and disorders in sexual functions of patients using psychotropic drugs. This scale is a Likert type self-assessment test consisting of five questions, and multiple forms to be filled by both men and women. In our study, the form for women has been used. This scale aims to evaluate sexual functions excluding the sexual orientation and the relationship with the spouse. In the form for women used in this study, there are questions addressing the sexual drive (ASEX1), psychological excitation (ASEX2), physiological excitation (vaginal lubrication) (ASEX3), capacity to reach orgasm (ASEX4) and satisfaction level after orgasm (ASEX5) respectively. Each question is scored ranging from 1 to 6 , and the total score varies from 5 to 30 . Low scores show that sexual respond is strong, easy and satisfactory, whereas high scores refer to the existence of sexual dysfunction. The higher the scores are, the more sexual dysfunction exist. Turkish acceptability and reliability works have been applied to the patients with end-stage renal failure (14).

\section{PSQI}

The Pittsburgh Sleep Quality Index was developed by Buysse et al. (15), and is a screening and evaluation test based on self-feedback. This index provides detailed information regarding sleep quality, type and severity of sleep disorder within the last one month. Consisting of 24 questions, the Pittsburgh Sleep Quality Index measures scores related to seven components. These are subjective sleep quality (PSQI1), sleep latency (PSQI2), sleep duration (PSQI3), habitual sleep efficiency (PSQI4), sleep disturbances (PSQI5), use of sleeping medication (PSQI6), and daytime dysfunction (PSQI7). In this index, there are five questions to be answered by the partner of the patients. However, these five questions are not used for scoring. Each item is weighted on a $0-3$ interval scale. The total score of seven components is equal to the total PSQI score. Total PSQII score may range from 0 to 21 . Scores that are equal to or less than 5 refer to "good" sleep quality, whereas scores more than 5 refer to "bad" sleep quality. Having a PSQI score higher than 5 means that the relevant person has serious difficulties at least in two components or has mild to moderate difficulties in more than three components. This Index's acceptability and reliability works in Turkish have been performed by Agargun et al. (16).

\section{HADS}

This is a scale developed to determine the anxiety and depression risk in patients with physical injuries and in those applied to primary care medical service and to measure its level and severity change (17). It has been translated into Turkish, and its acceptability and reliability tests have been carried out (18). It has sub-scales as Anxiety (HADS-A) and Depression (HADS-D). It contains 14 questions in total. Seven of them (odd numbers) measure the anxiety and other seven questions (even numbers) measure the depression level. It ensures quart Likert type measurement. In studies conducted in Turkey, anxiety sub-scale cut-off score was found 10/11, and depression sub-scale score was found $7 / 8$. Based on this result, patients who have more than $\mathrm{X}$ are considered as part of the risk group. The patients can get a minimum score of 0 and maximum score of 21 from the mentioned sub-scales. HADS is preferred due to the fact that it does not contain any substance related to physical symptoms.

\section{Statistical analysis}

Statistical analyses have been carried out by using IBM Statistical Package for the Social Sciences (IBM SPSS Corp.; Armonk, NY, USA) version 20. Conformity of variables to the normal distribution has been examined by visual (histogram and probability graphs) and analytical methods (Kolmogorov-Smirnov test). 
Sociodemographic data, sex frequency, sleep disorders and existence of sexual problem have been given by using cross tables. by using ChiSquare or Fisher tests, it has been decided if there was a difference between the groups in terms of the reported frequencies or not.

Descriptive analyses have been given by using median, 25 percent, 75 percent and interquartile range for non-normal distributed variables. Since age, PSQI, ASEX and HADS values did not show normal distribution, groups have been compared by using MannWhitney U test.

Correlation coefficients and statistical significances for the relation between variables of which at least one was non-normal or ordinal have been calculated by using Spearman test. Type 1 error level for statistical significance has been considered as $5 \%$.

\section{Table 1. Sociodemographic characteristics of patient and control group}

\begin{tabular}{|c|c|c|c|c|}
\hline & & $\begin{array}{c}\text { Patient } \\
\text { group } \\
\text { n (\%) }\end{array}$ & $\begin{array}{c}\text { Control } \\
\text { group } \\
\text { n (\%) }\end{array}$ & $\mathbf{p}$ \\
\hline Age & & $\begin{array}{c}53 \pm 33 \\
(m e a n \pm S D)\end{array}$ & $\begin{array}{c}52.5 \pm 33 \\
(\text { mean } \pm S D)\end{array}$ & 0.26 \\
\hline \multirow[t]{2}{*}{$\begin{array}{l}\text { Education } \\
\text { level }\end{array}$} & $\begin{array}{l}\text { Primary/ } \\
\text { High School }\end{array}$ & 40 (37) & $47(43.5)$ & 0.013 \\
\hline & University & $16(14.8)$ & $5(4.6)$ & \\
\hline \multirow[t]{2}{*}{$\begin{array}{l}\text { Working } \\
\text { status }\end{array}$} & $\begin{array}{l}\text { Not } \\
\text { working }\end{array}$ & $33(30.6)$ & $42(38.9)$ & 0.014 \\
\hline & Working & $23(21.3)$ & $10(9.3)$ & \\
\hline \multirow[t]{2}{*}{$\begin{array}{l}\text { Marital } \\
\text { status }\end{array}$} & Married & $43(39.8)$ & $45(41.7)$ & 0.192 \\
\hline & $\begin{array}{l}\text { Single/ } \\
\text { Divorced }\end{array}$ & $13(12)$ & $7(6.5)$ & \\
\hline \multirow{2}{*}{$\begin{array}{l}\text { Psychiatric } \\
\text { disease }\end{array}$} & Yes & $6(5.6)$ & $3(2.8)$ & 0.49 \\
\hline & No & $50(46.3)$ & $49(45.4)$ & \\
\hline \multirow{2}{*}{$\begin{array}{l}\text { Use of } \\
\text { cigarette }\end{array}$} & Yes & $4(3.7)$ & $17(15.7)$ & 0.001 \\
\hline & No & $52(48.1)$ & $35(32.4)$ & \\
\hline \multirow{2}{*}{$\begin{array}{l}\text { Use of } \\
\text { alcohol }\end{array}$} & Yes & $1(0.9)$ & $6(5.6)$ & 0.051 \\
\hline & No & $55(50.9)$ & $46(42.6)$ & \\
\hline \multirow{2}{*}{$\begin{array}{l}\text { Regular } \\
\text { partner } \\
\text { status }\end{array}$} & Yes & $39(36.1)$ & 28 (25.9) & 0.091 \\
\hline & No & $17(15.7)$ & $24(22.2)$ & \\
\hline \multirow{2}{*}{$\begin{array}{l}\text { Sex } \\
\text { problems }\end{array}$} & Yes & 15 (13.9) & $3(2.8)$ & 0.003 \\
\hline & No & $41(38)$ & $49(45.4)$ & \\
\hline \multirow[t]{2}{*}{$\begin{array}{l}\text { Sex } \\
\text { frequency }\end{array}$} & $\begin{array}{l}\text { 1>at one } \\
\text { month }\end{array}$ & $8(7.4)$ & $26(24.1)$ & 0.000 \\
\hline & $\begin{array}{l}1<\text { at one } \\
\text { month }\end{array}$ & $48(44.4)$ & $26(24.1)$ & \\
\hline \multirow{2}{*}{$\begin{array}{l}\text { Sleep } \\
\text { problems }\end{array}$} & Yes & $23(21.3)$ & $5(4.6)$ & 0.000 \\
\hline & No & $33(30.6)$ & $47(43.5)$ & \\
\hline
\end{tabular}

\section{Results}

Fifty-six patients with breast cancer meeting the criteria of study and 52 healthy women as the control group were included in this study. The average age of patient groups was $53 \pm 33$, and average age of control group was $52.5 \pm 33(p>0.05)$. When sociodemographic differences between the patient group and the control group were examined, it was seen that university graduates were significantly more in the patient group $(\mathrm{p}=0.013)$. In addition to this, it was determined that number of working women in the patient group was significantly higher $(\mathrm{p}=0.014)$. Sleep disorder and sexual problems were also significantly seen more frequently in the patient group $(\mathrm{p}=0.000, \mathrm{p}=0.003)$. When these two groups are compared in terms of sex frequency ( 4 times or more vs less than 4 times in a month), there was a significant difference between the groups. It was determined that sex frequency in the patient group was significantly decreased $(\mathrm{p}=0.000)(\mathrm{p}<0.05)$ (Table 1$)$.

Average of ASEX 1, ASEX 3, ASEX Total, PSQI1, PSQI2, PSQI3, PSQI4, PSQI5, PSQI6, HADS-A, HADS-D, HADS-T scale scores applied to the patient and control group were found statistically different in the patient group compared to the control group $(\mathrm{p}<0.05)$ (Table 2).

Based on the scale scores applied in pre-treatment period and posttreatment period; a significant difference has been observed between PSQI1, PSQI2, PSQI5, PSQI6, ASEX1, ASEX2, ASEX3, ASEX4, ASEX5, ASEX Total, HADS-D, HADS-A and HADS-T levels $(\mathrm{p}<0.05)$ (Table 3$)$.

In the correlation analysis performed among the pre-treatment PSQI, ASEX, HADS scale values, there was a negative correlation between PSQI and ASEX scores, and a positive correlation between PSQI and HADS scores (respectively: $\mathrm{r}$ : $-0.22, \mathrm{p}: 0.02 ; \mathrm{r}=0.61, \mathrm{p}=0.000$ ) $(\mathrm{p}<0.05)$. In the correlation analysis performed among the post-treatment PSQI, ASEX and HADS scale scores, a positive relation between PSQI, ASEX scores and PSQI, HADS scores was determined (respectively: $\mathrm{r}=0.27, \mathrm{p}=0.04 ; \mathrm{r}=0.46, \mathrm{p}=0.000)(\mathrm{p}<0.05)($ Table 4$)$.

\section{Discussion and Conclusion}

In patients with breast cancer, some serious psychological problems occur because of multiple reasons such as uncertainty about the treatment, physical symptoms, fear of recurrence and death, changes in female identity, body image perception and sexual functions, difficulties in daily life activities, lack of social and emotional support (19). Surgery, radiotherapy, chemotherapy or hormonal treatments for breast cancer treatment affect the physical and mental health of patients. As a result of this, symptoms such as depression, mood disorders, deterioration in body image perception, trauma in female identity and sexual dysfunction are seen (20). It has been observed that women with breast cancer, who HADS chemotherapy, HADS more physical problems and sexual dysfunctions than those who did not get chemotherapy, and that symptoms related to ovarian failure negatively affected the quality of life of the woman and their sexual relations with their partners (21).

When patients with breast cancer are compared to age-controlled healthy women, Meyerowitz et al. (22) found similar impacts of diagnosis and treatments on sexuality, and sexual function and satisfaction, however they also reported that sexual lives of approximately one-third of women with breast cancer were affected negatively and that those women HADS problems with their partners and lubrication disorder. 
Table 2. Comparison of ASEX, PUA, HADS scales of patient and control group

\begin{tabular}{|c|c|c|c|c|c|c|c|c|}
\hline & & $\mathbf{N}$ & 25 per & 50 per (median) & 75 per & IQR & Mean士SD & $\mathbf{p}$ \\
\hline \multirow[t]{3}{*}{ PSQI1 } & Patient & 56 & 1 & 1 & 2 & 1 & $1.39 \pm 0.65$ & 0.000 \\
\hline & Control & 52 & 0 & 1 & 1 & 1 & $0.56 \pm 0.50$ & \\
\hline & Total & 108 & & & & & & \\
\hline \multirow[t]{3}{*}{ PSQI2 } & Patient & 56 & 2 & 2 & 3 & 1 & $2.41 \pm 1.05$ & 0.000 \\
\hline & Control & 52 & 0 & 0 & 0.75 & 1 & $0.25 \pm 0.43$ & \\
\hline & Total & 108 & & & & & & \\
\hline \multirow[t]{3}{*}{ PSQI3 } & Patient & 56 & 0 & 0 & 1 & 1 & $0.73 \pm 0.86$ & 0.000 \\
\hline & Control & 52 & 0 & 0 & 0 & 0 & $0.1 \pm 0.29$ & \\
\hline & Total & 108 & & & & & & \\
\hline \multirow[t]{3}{*}{ PSQI4 } & Patient & 56 & 0 & 0 & 0 & 0 & $0.2 \pm 0.51$ & 0.058 \\
\hline & Control & 52 & 0 & 0 & 0 & 0 & $0.04 \pm 0.19$ & \\
\hline & Total & 108 & & & & & & \\
\hline \multirow[t]{3}{*}{ PSQI5 } & Patient & 56 & 1 & 2 & 2 & 1 & $1.63 \pm 0.62$ & 0.000 \\
\hline & Control & 52 & 1 & 1 & 1 & 0 & $1.06 \pm 0.46$ & \\
\hline & Total & 108 & & & & & & \\
\hline \multirow[t]{3}{*}{ PSQI6 } & Patient & 56 & 0 & 0 & 0 & 0 & $0.29 \pm 0.75$ & 0.001 \\
\hline & Control & 52 & 0 & 0 & 1 & 1 & $0.48 \pm 0.50$ & \\
\hline & Total & 108 & & & & & & \\
\hline \multirow[t]{3}{*}{ PSQI7 } & Patient & 56 & 0 & 0 & 0 & 0 & $0.29 \pm 0.65$ & 0.85 \\
\hline & Control & 52 & 0 & 0 & 0 & 0 & $0.27 \pm 0.52$ & \\
\hline & Total & 108 & & & & & & \\
\hline \multirow[t]{3}{*}{ PSQI-T } & Patient & 56 & 5 & 7 & 8 & 3 & $6.95 \pm 3.1$ & 0.000 \\
\hline & Control & 52 & 2 & 3 & 4 & 2 & $2.75 \pm 1.2$ & \\
\hline & Total & 108 & & & & & & \\
\hline \multirow[t]{3}{*}{ ASEX 1} & Patient & 56 & 4 & 5 & 5 & 1 & $4.36 \pm 1.13$ & 0.000 \\
\hline & Control & 52 & 5 & 5 & 6 & 1 & $5.06 \pm 1.22$ & \\
\hline & Total & 108 & & & & & & \\
\hline \multirow[t]{3}{*}{ ASEX 2} & Patient & 56 & 4 & 4 & 5 & 1 & $4.18 \pm 1.11$ & 0.067 \\
\hline & Control & 52 & 4 & 5 & 6 & 2 & $4.62 \pm 1.28$ & \\
\hline & Total & 108 & & & & & & \\
\hline \multirow[t]{3}{*}{ ASEX 3} & Patient & 56 & 4 & 4 & 5 & 1 & $4.38 \pm 1.03$ & 0.004 \\
\hline & Control & 52 & 4 & 5 & 6 & 2 & $4.88 \pm 1.21$ & \\
\hline & Total & 108 & & & & & & \\
\hline \multirow[t]{3}{*}{ ASEX 4} & Patient & 56 & 4 & 4 & 5 & 1 & $4.29 \pm 0.98$ & 0.099 \\
\hline & Control & 52 & 4 & 5 & 6 & 2 & $4.58 \pm 1.46$ & \\
\hline & Total & 108 & & & & & & \\
\hline \multirow[t]{3}{*}{ ASEX 5} & Patient & 56 & 3 & 4 & 5 & 2 & $4.20 \pm 1.19$ & 0.123 \\
\hline & Control & 52 & 4 & 5 & 6 & 2 & $4.52 \pm 1.4$ & \\
\hline & Total & 108 & & & & & & \\
\hline \multirow[t]{3}{*}{ ASEX-T } & Patient & 56 & 18.25 & 21.5 & 25 & 6.75 & $21.39 \pm 5$ & 0.011 \\
\hline & Control & 52 & 20 & 24 & 30 & 10 & $23.96 \pm 6.27$ & \\
\hline & Total & 108 & & & & & & \\
\hline
\end{tabular}


Table 2. Comparison of ASEX, PUA, HADS scales of patient and control group (continued)

\begin{tabular}{|c|c|c|c|c|c|c|c|c|}
\hline & & $\mathbf{N}$ & 25 per & 50 per (median) & 75 per & IQR & Mean士SD & $\mathbf{p}$ \\
\hline \multirow[t]{3}{*}{ HADS-D } & Patient & 56 & 13.25 & 16 & 17 & & $14.73 \pm 3.96$ & 0.000 \\
\hline & Control & 52 & 8 & 9 & 10 & & $8.73 \pm 1.99$ & \\
\hline & Total & 108 & & & & & & \\
\hline \multirow[t]{3}{*}{ HADS-A } & Patient & 56 & 14 & 16.5 & 19 & & $15.98 \pm 3.59$ & 0.000 \\
\hline & Control & 52 & 9 & 11 & 12 & & $10.46 \pm 2.07$ & \\
\hline & Total & 108 & & & & & & \\
\hline \multirow[t]{3}{*}{ HADS-T } & Patient & 56 & 26.5 & 32 & 36 & & $30.71 \pm 7.14$ & 0.000 \\
\hline & Control & 52 & 17.25 & 20 & 21 & & $19.19 \pm 3.19$ & \\
\hline & Total & 108 & & & & & & \\
\hline
\end{tabular}

p<0.05. HADS: Hospital Anxiety Depression Scale; HADS-A: Anxiety subscale; HADS-D: Depression subscale; HADS-T: Total scale; PSQI: Pittsburgh Sleep Quality Scale; PSQI1: Sleep latency; PSQI2: Subjective sleep quality; PSQI3: Sleep duration; PSQI4: Habitual sleep efficiency; PSQI5: Sleep disturbances; PSQI6: Use of sleeping medication; PSQI7: Daytime dysfunction; PSQI-T: Total scale; ASEX: Arizona Sexual Life Scale; ASEX1: Sexual drive; ASEX2: Psychological excitation; ASEX3: Vaginal lubrication; ASEX4: Capacity to reach orgasm; ASEX5: Satisfaction level after orgasm; ASEX-T: Total scale per: percentile; IQR: Inter quartile range

Table 3. Comparison of patients' scores before and after treatment

\begin{tabular}{|c|c|c|c|c|c|c|c|c|c|}
\hline & \multicolumn{3}{|c|}{ Before treatment } & \multirow[b]{2}{*}{ Mean士SD } & \multicolumn{3}{|c|}{ After treatment } & \multirow[b]{2}{*}{ Mean士SD } & \multirow[b]{2}{*}{$\mathbf{P}$} \\
\hline & 25 per & 50 per & 75 per & & 25 per & 50 per & 75 per & & \\
\hline PSQI1 & 1 & 1 & 2 & $1.39 \pm 0.65$ & 0 & 1 & 1 & $0.79 \pm 0.75$ & 0.000 \\
\hline PSQI2 & 2 & 2 & 3 & $2.41 \pm 1.05$ & 1 & 1 & 2 & $1.54 \pm 1$ & 0.000 \\
\hline PSQI3 & 0 & 0 & 1 & $0.73 \pm 0.86$ & 0 & 0 & 1 & $0.68 \pm 0.87$ & 0.47 \\
\hline PSQI4 & 0 & 0 & 0 & $0.2 \pm 0.51$ & 0 & 0 & 0 & $0.23 \pm 0.66$ & 0.79 \\
\hline PSQI5 & 1 & 2 & 2 & $1.63 \pm 0.62$ & 1 & 1 & 1 & $1.16 \pm 0.41$ & 0.000 \\
\hline PSQI6 & 0 & 0 & 0 & $0.29 \pm 0.75$ & 0 & 0 & 0 & $0.16 \pm 0.53$ & 0.053 \\
\hline PSQI7 & 0 & 0 & 0 & $0.29 \pm 0.65$ & 0 & 0 & 0 & $0.18 \pm 0.43$ & 0.32 \\
\hline PSQI-T & 5 & 7 & 8 & $6.95 \pm 3.15$ & 3 & 4 & 5.75 & $4.75 \pm 2.57$ & 0.000 \\
\hline ASEX 1 & 4 & 5 & 5 & $4.69 \pm 1.22$ & 4.25 & 5 & 6 & $5.13 \pm 1$ & 0.000 \\
\hline ASEX 2 & 4 & 4 & 5 & $4.39 \pm 1.21$ & 4 & 5 & 6 & $4.95 \pm 1$ & 0.000 \\
\hline ASEX 3 & 4 & 4 & 5 & $4.62 \pm 1.15$ & 4 & 5 & 6 & $4.93 \pm 1$ & 0.009 \\
\hline ASEX 4 & 4 & 4 & 5 & $4.43 \pm 1.24$ & 4 & 5 & 6 & $4.86 \pm 1$ & 0.014 \\
\hline ASEX 5 & 3 & 4 & 5 & $4.35 \pm 1.3$ & 4 & 5 & 6 & $4.86 \pm 1.2$ & 0.014 \\
\hline ASEX-T & 18.25 & 21.5 & 25 & $22.63 \pm 5.77$ & 22.25 & 25 & 29 & $25.02 \pm 5.2$ & 0.001 \\
\hline HADS-D & 13.25 & 16 & 17 & $11.84 \pm 4.36$ & 5 & 8 & 10 & $7.95 \pm 4.22$ & 0.000 \\
\hline HADS-A & 14 & 16.5 & 19 & $13.32 \pm 4.04$ & 6.25 & 8 & 12.75 & $9.07 \pm 4.18$ & 0.000 \\
\hline HADS-T & 26.5 & 32 & 36 & $25.17 \pm 8.03$ & 11.25 & 16 & 22.75 & $17.02 \pm 7.84$ & 0.000 \\
\hline
\end{tabular}

In another study, there was no significant difference in sexual dysfunctions between Patients who received medical treatment after the surgical intervention and those who did not. More than half of the women stated that they HADS sexual problems before breast cancer, and about half of the Patients stated that their sexual problems started after breast cancer treatment. They said that chemotherapy HADS negative effects on their sexual life. In approximately half of women, it was observed that breast cancer and its treatments HADS a negative effect on both their relationships with their partners and sexual lives. More than half of the women with breast cancer HADS sexual dysfunction 


\section{Table 4. Correlation analysis of PSQI, ASEX, HADS total scores before and after treatment}

\begin{tabular}{|c|c|c|c|c|}
\hline & & PSQI & ASEX & HADS \\
\hline \multirow[t]{4}{*}{ PSQI } & Before treatment & - & r:-0.22 & $r=0.61$ \\
\hline & & & $\mathrm{p}: 0.02$ & $p=0.000$ \\
\hline & After treatment & - & $r=0.27$ & $r=0.46$ \\
\hline & & & $p=0.04$ & $p=0.000$ \\
\hline \multirow[t]{4}{*}{ ASEX } & Before treatment & г:-0.22 & - & $r=-0.08$ \\
\hline & & $\mathrm{p}: 0.02$ & & $p=0.36$ \\
\hline & After treatment & $r=0.27$ & - & $r=0.26$ \\
\hline & & $p=0.04$ & & $p=0.051$ \\
\hline \multirow[t]{4}{*}{ HADS } & Before treatment & $r=0.61$ & $r=-0.08$ & - \\
\hline & & $p=0.000$ & $p=0.36$ & \\
\hline & After treatment & $r=0.46$ & $r=0.26$ & - \\
\hline & & $p=0.000$ & $p=0.051$ & \\
\hline
\end{tabular}

(23). In our study, it was seen that the Patients HADS decreased sexual function compared to the control group. However, in our before and after treatment comparisons; we have found that sexual functions have increased significantly in the post-treatment period, compared to the pre-treatment levels despite the treatment process and the side effects that might be secondary to the treatment.

The most common psychiatric illnesses in the Patients with breast cancer are depression and anxiety. Comorbidity of the depression occurring together with breast cancer is $46 \%$ which is a high rate; this rate increases within the first year after the diagnosis (18). In a study conducted, a negative correlation has been seen between anxiety scores and body image, future expectation and sexual function (24). When depressive score levels were compared as pre-treatment period and post-treatment period; it has been determined that depressive symptoms increased by $20 \%$ between 0 and $6^{\text {th }}$ month, $12.9 \%$ between $6^{\text {th }}$ and $12^{\text {th }}$ month (25). In our study; depression and anxiety scores of the Patients were higher than those of the control group, and anxiety and depression were seen in pre-treatment period more often than in post-treatment period. Furthermore, there was a weak positive correlation between depression and anxiety scores and sexual function scores after the treatment.

Sleep disorders are commonly seen in breast cancer patients. Even after multiple years after the initial diagnosis, sleep disorders continue in some Patients (26). When the quality of sleep was examined in two hundred Patients with breast cancer, it was determined that $38 \%$ of them HADS poor quality sleep. It was shown that there was no significant correlation between sleepiness in daytime, depression and sleep quality (27). In another study; $43 \%$ of Patients with breast cancer HAD sleep disorders. Intrusive thoughts related to breast cancer were found to result in just $12 \%$ of the severity of insomnia symptoms. It was reported that these thoughts were an important determinant of insomnia symptoms. It was thought that emotional distress and anxiety that might arise from intrusive thoughts could eventually result in deficiencies in sleep and daytime functioning (28). It was observed that survivors among the sample consisting sleep quality and physical and mental health of them were worse than those without cancer. It was reported that sleep quality was an important determinant of mental and physical health (29). In a prospective study examining the relationship between sleep times and breast cancer, a relationship was found between short duration of sleep and breast cancer risk. This situation has been explained with the anti-proliferative effect of the melatonin hormone on breast cancer cells and its suppressive feature on gonadal secretion (30). In our study, it was found that Patients group HAD a significant deterioration in the sleep scores compared to the control group. $23 \%$ of the Patients HAD sleep problems, and the sleep disturbance continued after the treatment but it is decreased compared to the pre-treatment period. There was a positive correlation between sleep scores and anxiety/depression scores and a negative correlation with sexual function scores. It was observed that sleep disorder was associated with anxiety and depression scores in post-treatment period.

Our study finds that the Patients with breast cancer have higher anxiety, depression, sleep disorder scores than control group, whereas sexual function levels of them are lower than the control group. Moreover, compared to pre-treatment period, an improvement in sleep quality, sexual function, anxiety and depression levels in post-treatment period was revealed. Sleep and sexual function were shown to be associated with anxiety and depression. Similar to studies in the literature, we confirm that treatments such as diagnosis and surgery, chemotherapy and hormone therapy in breast cancer Patients affect the physical and mental health of patients. However, in this study, it was observed that psychological symptoms such as anxiety and depression in posttreatment period as well as changes in the sexual life and sleep, which are both symptoms of physical and mental disorders, improved compared to the pre-treatment period. The results of this study showed that psychosocial support in breast cancer patients during diagnosis and pre-treatment period is more important than the support in posttreatment period. Because anxiety, depression, sleep disorder score levels in the patients with breast cancer are higher in the pre-treatment period, whereas sexual function levels are lower compared to the posttreatment period. 
Ethics Committee Approval: Ethics committee approval was received for this study from the ethics committee of Demiroğlu Bilim University (Date: 02.08.2017 No: 44140529/2017-80).

Informed Consent: Written informed consent was obtained from the participants.

Peer-review: Externally peer-reviewed.

Author Contributions: Concept - F.İ., G.Ö.; Design - G.Ö., Ö.İ.D., G.Ö., F.E., F.İ.; Supervision - Z.E., V.Ö., F.A., A.Ö., G.Ö., A.S.İ.; Funding - V.Ö., F.A., Ç.O., F.E., F.İ., A.Ö., T.D.; Materials - F.A., F.E., F.İ., K.C.A., A.S.İ., T.D.; Data Collection and/or Processing - F.̇., F.E., F.A., K.C.A., Ö.İ.D.; Analysis and/or Interpretation - F.İ., A.S.İ., Z.E., Ç.O., A.Ö.; Literature Review - F.İ., F.A., V.Ö., A.Ö., K.C.A.; Writing - F.İ., A.S.İ., Ö.İ.D., T.D., G.A.; Critical Review - V.Ö., F.A., A.S.İ., G.A., Ç.O.

Conflict of Interest: The authors have no conflicts of interest to declare.

Financial Disclosure: The authors declared that this study has received no financial support.

\section{References}

1. Christensen H, Marck D. The efficacy of mindfulness based stress reduction (MBSR) for decreasing anxiety and depression among breast cancer survivors. Sch Physician Assist Stud 2017; 16: 613.

2. Lueboonthavatchai P. Prevalence and psychosocial factors of anxiety and depression in breast cancer patients. J Med Assoc Thai 2007; 90: 21642174. (PMID: 18041438)

3. Rogers LQ, Courneya KS, Anton PM, Verhulst S, Vicari SK, Robbs RS, McAuley E. Effects of a multicomponent physical activity behavior change intervention on fatigue, anxiety, and depressive symptomatology in breast cancer survivors: randomized trial. Psychooncology 2017; 26: 1901-1906. (PMID: 27530961) [Crossref]

4. Maass SWMC, Roorda C, Berendsen AJ, Verhaak PF, de Bock GH. The prevalence of long-term symptoms of depression and anxiety after breast cancer treatment: A systematic review. Maturitas 2015; 82: 100-108. (PMID: 25998574) [Crossref]

5. Vahdaninia M, Omidvari S, Montazeri A. What do predict anxiety and depression in breast cancer patients? A follow-up study. Soc Psychiatry Psychiatr Epidemiol 2010; 45: 355-361. (PMID: 19458878) [Crossref]

6. Reich M, Lesur A, Perdrizet-Chevallier C. Depression, quality of life and breast cancer: a review of the literature. Breast Cancer Res Treat 2008; 110: 9-17. (PMID: 17674188) [Crossref]

7. Savard J, Ivers H, Villa J, Caplette-Gingras A, Morin CM. Natural course of insomnia comorbid with cancer: an 18-month longitudinal study. J Clin Oncol 2011; 29: 3580-3586. (PMID: 21825267) [Crossref]

8. Chen PJ, Huang CL, Weng SF, Wu MP, Ho CH, Wang JJ, Tsai WC, Hsu YW. Relapse insomnia increases greater risk of anxiety and depression: evidence from a population-based 4-year cohort study. Sleep Med 2017; 38: 122-129. (PMID: 29031746) [Crossref]

9. Can G. Kanserde cinsel sağlık. Androloji Bülteni Hemşire Çalışma Grubu 2004; 19: 355-356.

10. Eti F. Mastektomili hastalara ameliyat öncesi ve sonrası uygulanan hemşirelik bakımının beden imajını algılama ve fiziksel iyileşme üzerine etkisi. İstanbul Üniversitesi Sağlık Bilimleri Enstitüsü Cerrahi Hastalıkları Hemşireliği Anabilim Dalı, Doktora Tezi, İstanbul. 1992

11. First MB, Spitzer RL, Gibbon M, Williams JBW. Structured Clinical Interview for DSM-IV Clinical Version (SCID-I/CV). American Psychiatric Press, Washington D.C 1997.

12. Çorapcıoğlu A, Aydemir Ö, Yıldız M, Esen A, Köroğlu E. DSM-IV Eksen I Bozuklukları (SCID-I)için yapılandırılmış klinik görüşme, klinik versiyon. Hekimler Yayın Birliği Matbaası, Ankara, 1999.
13. Mcgahuey CA, Gelenberg AJ, Laukes CA, Moreno FA, Delgado PL, McKnight KM, Manber R. The Arizona Sexual Experience Scale (ASEX): Reliability and Validity. J Sex Marital Ther 2006; 26: 25-40. (PMID: 10693114) [Crossref]

14. Soykan A. The reliability and validity of Arizona sexual experiences scale in Turkish ESRD patients undergoing hemodialysis. Int J Import Res 2004; 16: 531-534. (PMID: 15175639) [Crossref]

15. Buysse DJ, Reynolds CF 3rd, Monk TH, Berman SR, Kupfer DJ. The pittsburgh sleep quality index: a new instrument for psychiatric practice and research. Psychiatric Res 1989; 28: 193-213. (PMID: 2748771) [Crossref]

16. Agargun MY. Pittsburgh uyku kalitesi indeksinin gecerligi ve guvenirligi. Turk Psikiyatri Dergisi 1996; 7: 107-115.

17. Zigmond AS, Snaith PR. The Hospital Anxiety and Depression Scale. Acta Psychiatr Scand 1983; 67: 361-370. [Crossref]

18. Aydemir Ö. Validity and Reliability of Turkish Version of Hospital Anxiety and Depression Scale. Turkish Journal of Psychiatry 1997; 8: 280-287.

19. Schidmit-Buchi S, Halfens RJ, Dassen T, van den Borne B. A review of psychosocial needs of breast-cancer patients and their relatives. J Clin Nurs 2008; 17: 2895-2909. (PMID: 19012759) [Crossref]

20. Reich M, Lesur A, Perdrizet-Chevallier C. Depression, quality of life and breast cancer: a review of the literature. Breast Cancer Res Treat 2007; 110: 9-17. (PMID: 17674188) [Crossref]

21. Wilmoth MC, Coleman EA, Smith SC, Davis C. Fatigue, weight gain, and altered sexuality in patient with breast cancer: Exploration of a symptom cluster. Oncology Nursing Forum 2004; 31: 1069-1075. (PMID: 15547630) [Crossref]

22. Meyerowitz BE, Desmond KA, Rowland JH, Wyatt GE, Ganz PA. Sexuality following breast cancer. J Sex Marital Ther 1999; 25:237-250. (PMID: 10407796) [Crossref]

23. Aygin D, Aslan FE. A Study of Sexual Dysfunction in Women with Breast Cancer. Eur J Breast Health 2008; 4: 105-114.

24. Fatiregun OA, Olagunju AT, Erinfolami AR, Arogunmati OA, Fatiregun OA, Adeyami JD. Relationship between anxiety disorders and domains of health related quality of life among Nigerians with breast cancer. Breast 2017; 31: 150-156. (PMID: 27866090) [Crossref]

25. Jones SM, LaCroix AZ, Li W, Zaslavsky O, Wassertheil-Smoller S, Weit ᄀlauf J, Brenes GA, Nassir R, Ockene JK, Caire-Juvera G, Danhauer SC. Depression and quality of life before and after breast cancer diagnosis in older women from the Women's Health Initiative. J Cancer Surviv 2015; 9: 620-629. (PMID: 25708515) [Crossref]

26. Savard J, Simard S, Blanchet J, Ivers H, Morin CM. Prevalence, clinical characteristics, and risk factors for insomnia in the context of breast cancer. Sleep 2001; 24: 583-590. (PMID: 11480655) [Crossref]

27. Lowery-Allison AE, Passik SD, Cribbet MR, Reinsel RA, O'Sullivan B, Norton L, Kirsh KL, Kavey NB. Sleep problems in breast cancer survivors 1-10 years posttreatment. Palliat Support Care 2018; 16: 325-334. (PMID: 28508735) [Crossref]

28. Taylor TR, Huntley ED, Makambi K, Sween J, Adams-Campbell LL, Frederick W, Mellman TA. Understanding sleep disturbances in AfricanAmerican breast cancer survivors: a pilot study. Psychooncology 2012; 21 : 896-902. (PMID: 21648016) [Crossref]

29. Rafie C, Ning Y, Wang A, Gao X, Houlihan R. Impact of physical activity and sleep quality on quality of life of rural residents with and without a history of cancer: findings of the Day and Night Study. Cancer Manag Res 2018; 10: 5525-5535. (PMID: 30519100) [Crossref]

30. Cao J, Eshak ES, Liu K, Muraki I, Cui R, Iso H, Tamakoshi A, JACC Study Group. Sleep duration and risk of breast cancer: The JACC Study. Breast Cancer Res Treat 2019; 174: 219-225. (PMID: 30460465) [Crossref] 